\title{
PERSPECTIVAS DE DESIGUALDADES SOCIAIS NO CURSO DE GRADUAÇÃO EM ADMINISTRAÇÃO PÚBLICA DE UMA UNIVERSIDADE PÚBLICA FEDERAL
}

http://dx.doi.org/10.5902/2318133829657

\author{
Vinicius Ferreira Baptista \\ Wanderson Cesar dos Santos \\ Universidade Federal Rural do Rio de Janeiro, Brasil.
}

\begin{abstract}
Resumo
Neste texto discute-se a percepção de estudantes do curso de graduação em Administração Pública de uma universidade federal em relação às dimensões de desigualdades sociais de gênero, raça e diversidade sexual. Apoiamo-nos na análise bibliográfica e pela pesquisa de campo. Percebemos que as três dimensões são pouco discutidas, quando não negligenciadas, o que provoca resistência e pouca abertura às mesmas, gerando incômodos quando são abordadas. Ao se negligenciar, propositadamente, a abordagem das três dimensões, ou de outras que tratem de grupos sociais marginalizados, põe-se em xeque a universidade como local de debate e reflexão sobre ideias e problemas sociais.

Palavras-chave: projeto pedagógico, administração pública, desigualdades sociais.
\end{abstract}

\section{SOCIAL INEQUALITIES PERCEPTIONS IN THE PUBLIC ADMINISTRATION COURSE IN A PUBLIC FEDERAL UNIVERSITY}

Abstract

This paper discuss the perception of students of the Public Administration Undergraduate Course in a Federal University regarding the dimensions of social inequalities of gender, race and sexual diversity. We rely on bibliographical methodologies and field research. We perceive that the three dimensions are little discussed, if not neglected, which causes resistance and little openness to them, generating annoyances then, in fact, they are approached. By purposely neglecting the approach of the three dimensions, or others that deal with marginalized social groups, the more we question the University as a place for debate and reflection on social ideas and problems.

Key-words: pedagogical project, public administration, social inequalities. 


\section{Introdução}

$\mathrm{O}$ presente texto tem como tema a problematização de como as dimensões de desigualdade social estão percebidas em estudantes em curso de graduação em uma universidade federal. As dimensões trabalhadas envolvem as desigualdades sociais no que referem a gênero, raça e diversidade sexual.

O objetivo é discutir a percepção de estudantes do curso de graduação em Administração Pública de uma universidade federal, aqui denominada universidade $X$, em relação às dimensões de desigualdades sociais de gênero, raça e diversidade sexual e visualizar a necessidade de que o curso, em seu projeto político-pedagógico, reforce o trabalho interdisciplinar destas dimensões em seu currículo.

Para tanto, nos apoiamos em duas metodologias específicas: a bibliográfica e documental, com o uso de documentos oficiais da referida instituição, a exemplo do próprio projeto pedagógico do curso, assim como as diretrizes curriculares nacionais DCN - no âmbito dos cursos de graduação em Administração Pública contidas em portaria do Conselho Nacional de Educação - CNE -, assim como a partir de literatura científica pertinente às dimensões das desigualdades analisadas. Paralelamente, realizou-se pesquisa de campo empreendida com estudantes do curso de graduação em Administração Pública.

O texto está estruturado em cinco partes. Na primeira situamos as desigualdades sociais e a universidade pública. Em seguida, analisamos as questões de gênero, racismo e diversidade sexual no âmbito de projetos político-pedagógicos. Na terceira parte nos apoiamos nas dimensões de gênero, racismo e diversidade sexual no curso de graduação em Administração Pública da universidade $X$. Na quarte parte consta a análise crítica da percepção dos estudantes do curso. Por último temos as considerações finais.

Entendemos que existe um descompasso da formação do curso de graduação em Administração Pública da universidade $X$. Tal formação não é balizada no âmbito da compreensão das desigualdades sociais porque ela as renega em termos de seus elementos básicos, além de não preparar o estudante para análise crítica da realidade social. Trata-se de formação mecânica e engessada que apresenta descompasso entre o plano teórico defendido pelo projeto pedagógico e sua pedagogia em si, retratada na matriz e ementas das disciplinas que a compõe.

As três dimensões são pouco discutidas - ainda que, por exemplo, tendo bibliografias citadas por estudantes -, quando não negligenciadas, o que provoca resistência e pouca abertura às mesmas, gerando incômodos quando, de fato, são abordadas. E, quanto menos se abordassem as três dimensões, ainda se terá a naturalização de determinados papeis sociais subalternos e até mesmo violentos.

Percebemos que, ao se negligenciar a abordagem das três dimensões, ou de outras que tratem de grupos sociais marginalizados, põe-se em xeque a universidade como local de debate e reflexão sobre ideias e problemas sociais. 


\section{As desigualdades sociais e a universidade pública}

Como poderíamos pensar, conceitual e em prática cotidiana, uma universidade aberta às diferenças? Pensar em respostas educativas é pensar em suas responsabilidades. Isso tem a ver com a universidade em si, seu corpo técnico, docentes e alunos, sem desconsiderar a comunidade entorno da universidade. Esta não é uma ilha e não deveria se estruturar como um sistema fechado.

A universidade não é um espaço homogêneo, então, nesta lógica, não deveria totalizar o corpo discente, nem o ambiente como um todo, construindo uma presenta uniformidade. A proposta de uma formação humanista incide sobre observar e compreender as diferenças e, especialmente, discutir e articular ações para que estas diferenças façam parte reconhecida da estrutura social, institucional e política, sem qualquer possibilidade de negligência, silenciamento e exclusão. A inação, tal como entendimento por Thomas Dye (2013) também é, além de ato político, a significação do ato de intervenção estatal: a política pública. Inação envolve clara percepção de não reconhecimento e ação concreta de silenciamento.

Quais os impactos que as desigualdades estruturantes - sociais, econômicas, recursos públicos, serviços públicos, cidadania, dentre outros - são capazes de construir num ambiente universitário e no processo formativo, além do profissional formado pelas universidades? No caso do curso de graduação em Administração Pública da universidade $X$ essas desigualdades teriam impactos na formação de um profissional que por se envolver com questões públicas, tem total interesse nessas perspectivas da desigualdade.

Isso corrobora o entendimento de que não há qualquer possibilidade justificável que exclua a questão da desigualdade, enquanto conceito, e de suas vertentes - enquanto decorrentes de processos cumulativos e históricos - da formação do administrador público. Este profissional tem a prerrogativa, pelos instrumentos analíticos de sua formação, de apreender as desigualdades no âmbito social, verificar alternativas palpáveis de intervenção estatal e produzir ambiente mais equitativo economicamente, socialmente justo e inclusivo política e institucionalmente.

Arroyo (2010) pondera que já existe um acúmulo de produção intelectual acerca de complexos processos de produção e reprodução das desigualdades mas que tal produção de estudos "nem sempre foram levados em conta na formulação e gestão, nas análises e avaliações, nem nas justificativas de diretrizes" (p. 1383). Todavia, o autor considera que o que mais se leva em consideração é o ambiente educacional e as desigualdades internas, desconsiderando a complexidade das desigualdades estruturantes.

Vamos a um exemplo prático: qualquer universidade que pense em políticas de permanência de mulheres no ambiente universitário vai levar em consideração as desigualdades internas e até mesmo as externas, a exemplo, da gravidez. A partir daí cria uma série de políticas, a exemplo de creches, entretanto, não cria políticas relativas ao acesso à pós-graduação, que negligencia candidatas mulheres na faixa etária dos trinta anos - momento em que, teoricamente, as mulheres têm mais predisposição à gravidez $\mathrm{e}$ isso poderia, na visão conservadora misógina e machista, trazer dificuldades ao programa 
de pós-graduação, porque a aluna trancaria o semestre ou até mesmo abandonaria o curso. Tendo esse exemplo prático, a criação de creches, isso é inócuo se a desigualdade estruturante - o machismo e misoginia - não são igualmente atacadas no processo de formulação das políticas.

Pensa-se, então, no que Atkinson (2015) entende por desigualdade de oportunidades - o acesso, e não no âmbito da desigualdade de resultados - o ex post, que também deve ser pensado na política pública. A desigualdade - um elemento conceitual que envolve alguma disparidade em termos de equivalência dentre pessoas - se situa em dois aspectos: a de oportunidades, que perpassa as condições materiais no plano em que as pessoas disputam e, em outro sentido, o de resultados, que compreende os resultados produzidos pelas intervenções que visam equilibrar as condições pensadas no primeiro aspecto.

Determinada política pública que procure tornar mais equitativo o acesso ao ensino superior - ações para a oportunidade - também precisa observar ações para o momento em que as pessoas o adentram: ações para os resultados. Não basta que se amplie as condições de entrada no ensino superior, mas que se tenham ações estruturantes que mantenham as pessoas neste sistema. Do contrário, não se pensa em desestruturar a desigualdade no processo em cadeia da mesma: apenas se está mitigando ou, nem isso, até mesmo fortalecendo a desigualdade, porque além de não a desestruturar, se põe em questionamento a existência da mesma. Neste sentido, seguimos o conceito de desigualdade contido em Atkinson (2015).

A educação é processo social e tem intrínseca relação com as desigualdades, independentemente da vertente, complexidade e profundidade. Por várias vezes serve como base de diferenciação social e de privilégios. Ao mesmo tempo, serve como estrutura de processos totalizantes de controle social e político, como também sustenta Foucault (1979) na análise de escolas, hospícios e penitenciárias. Então não há como se desconsiderar a educação na correlação com as desigualdades sociais, uma vez que a primeira influencia e é influenciada pela segunda reciprocamente.

Arroyo (2010) destaca a ideia de que em muitas políticas se enfatizam as desigualdades a corrigir e os deveres do Estado, como se as desigualdades fossem vistas sem sujeitos e unicamente como campo de intervenção. A discussão sobre desigualdades é abstrata, pouco complexa, muito rasa. Tendo como foco os sujeitos coletivos desiguais, termo de Arroyo (2010) usa para delimitar os assujeitados pelas desigualdades em várias vertentes: a própria desigualdade é repensada, deixando o aspecto unívoco.

Os sujeitos coletivos desiguais são desconsiderados das análises, as pessoas são totalizadas e as desigualdades são uniformizadas, como se todas estas fossem produzidas e reproduzidas uniformemente pelas mesmas bases: o que impacta em políticas lineares, praticamente de causa e efeito, de mero cumprimento de um dever do Estado para com a sociedade, com o objetivo de resolver seus problemas. Os desiguais se tornam um problema e as políticas se configuram com solução. E o contexto estrutural é desconsiderado, quando não esquecido ou até mesmo inferiorizado.

Os desiguais são considerados como desiguais num mero sentido nominativo, que aponta a existência de pessoas desiguais entre si: seja em vertente econômica, social, política, cultural ou institucional, sendo a ênfase, notadamente, para o primeiro aspecto. Esse sentido nominativo é acompanhado pela noção da meritocracia e do darwinismo - a 
escolha em ser miserável ou desigual, porque não estudou, não trabalhou, não produziu, onde diversos fatores culpabilizantes além disso são introduzidos na análise da desigualdade. Esse foco produz, unicamente, o Estado como solução e análises do tipo tratar os iguais como iguais e os desiguais como desiguais, porque apenas se nominam os desiguais; não se observa a estrutura da desigualdade - o que está em jogo, além do aspecto ideológico, é também o aspecto conceitual, das ideias totalizantes que obscurecem atores, processos, instituições, normas, códigos, valores morais e éticos que estruturam e coordenam a base social produzida e reproduzida historicamente.

Arroyo (2010) entende que essa ocultação da desigualdade, além de vitimizar os desiguais como produtores das desigualdades e como problemas, subsidia a produção, pelo Estado, de "políticas de segurança, de ordem, de controle" (Arroyo, 2010, p. 1393), o que implica em controlar aqueles que são desiguais a ambientações que exigem um comportamento, num claro sentido de políticas moralizantes.

Tendo em vista a percepção do aluno em universidades públicas, o estudante em nível superior deve ter capacidade crítica e analítica para entender o próprio ambiente em que está inserido. Especificamente um estudante do curso de graduação em Administração Pública tem como base analítica a ação estatal no âmbito da produção de mudanças sociais. Como se pode ter um estudante que estuda conceitualmente as desigualdades e sequer reflete sobre as desigualdades, por exemplo, em sua própria sala de aula? Onde está a capacidade reflexiva e o sujeito crítico pensado pelos projetos políticos pedagógicos? Sua capacidade crítica é para além da bolha universitária?

Sassaki (2005), ao afirmar que a inclusão implica adequar os sistemas sociais gerais da sociedade de tal modo que sejam eliminados os fatores que excluíam certas pessoas, defende que "o desenvolvimento (por meio da educação, reabilitação etc.) das pessoas com deficiência deve ocorrer dentro do processo de inclusão e não como um prérequisito" (p. 23). O referido autor define inclusão como um paradigma de sociedade que implica a adequação dos sistemas sociais a toda a diversidade humana, com diferentes atributos quanto à raça, língua, nacionalidade, gênero, orientação sexual, deficiência, entre outros, assim como prevê a participação das diversas pessoas na proposição e realização das adequações que se fizerem necessárias (Sassaki, 2009). Neste sentido, a desigualdade não pode ser observada como processo unilateral nem pensada, no campo da intervenção, em processos lineares de causa e efeito, descoladas de processos estruturantes e históricos.

Existe um sentido mais perverso nessa proposta moralizante: a existência de um "Estado regulador das desigualdades e da exclusão" (Arroyo, 2010, p. 1410). Por um lado, um Estado que negligencie as diferenças denota a clara não percepção dos cidadãos como indignos de algum alcance à cidadania. De outro lado, em sentido complementar, um Estado que regule as desigualdades e a inclusão pela simples perspectiva de não ruptura da estrutura social pela insatisfação - uma espécie de gestão das desigualdades vê o ambiente desigual e os seus contextos produtores e reprodutores não como passiveis de desestruturação e rompimento, mas como parte constituinte, aceitável e naturalmente atrelada à estrutura da sociedade. O que vemos nesse Estado regulador, é um Estado que gerencia as desigualdades em termos aceitáveis para o que Castel (2010) entende como coesão social. Assim, esta noção nos leva para o entendimento sobre cidadania. 
Holston (2013) inicia sua argumentação sobre cidadania abordando que "todos os Estados nacionais lutam para administrar as diferenças sociais que distinguem entre seus habitantes" (p. 21). Isso leva à compreensão do processo de correlação de forças e de disputas ideológicas na luta de classes, especificamente, nas disputas pelas ações do Estado que balizarão as ações que aprofundarão ou diminuirão as diferenças sociais.

Ao mesmo tempo, leva-se à compreensão de que existe uma gestão propriamente dita daquilo o que Castel (2010) entenderá por coesão social, de modo que as ações do Estado se determinam pelas propriedades resultantes das disputas de correlação de forças, em um sentido e, do outro, de ações que venham a manter uma certa coesão entre habitantes dessa sociedade, de maneira que as diferenças não sejam abruptas a ponto de corroer o tecido social, notadamente, um modo de gestão especifico das desigualdades que não estejam tão desiguais assim.

Se há progresso, há também regresso no que toca à cidadania, em termos de distribuição de direitos e exercício dos mesmos. No sentido de que ao mesmo tempo em que surgem processos políticos e institucionais que proliferam e insurgem participações democráticas, institucionais ou não, formais ou não, existe "um emaranhado entre a democracia e seus opositores", em que surgem novos tipos de cidadãos e, paralelamente, novas formas de violência e exclusão que a corroem (Holston, 2010, p. 21). Um processo de mão dupla, em que o alcance de novos direitos e exercício de cidadania acaba sendo percebido como perigoso e danoso ao exercício de poder de determinados grupos que, ao ver isso como perda de privilégios, entende que tal processo deve ser combatido.

Essa questão de, por um lado, existir a desigualdade e diversos mecanismos para sua diminuição e, do outro lado, uma disputa por atores com maiores capacidades por manutenção de status quo e do alto grau de desigualdade é capaz de estruturar uma sociedade. Atkinson (2015) entende que a proporção da desigualdade é capaz de produzir efeitos sobre a sociedade. Tais efeitos não se restringem apenas à sociedade do tempo histórico em que se analisa tal desigualdade, mas que os mesmos se processam pela intergeracionalidade, ou seja, se manterão nas gerações seguintes, de modo a reproduzir a desigualdade historicamente, mantendo bases de status quo que negligenciam parte da população em detrimento de outras.

Assim, convém debatermos sobre como a universidade, especificamente no âmbito da graduação em Administração Pública é capaz de formar profissionais que sejam atentos a tais questões das diversas dimensões da desigualdade social, ao mesmo tempo em que possuam capacidade de propor ações para a mudança do quadro social.

\section{As questões de gênero, racismo e diversidade sexual no âmbito de projetos políticos pedagógicos}

Em 2014, o Ministério da Educação, via Conselho Nacional de Educação, publicou a resolução $\mathrm{n}$. 1, de 13 de janeiro de 2014, que institui as diretrizes curriculares nacionais do curso de graduação em Administração Pública, bacharelado, e dá outras providências. Neste sentido, qualquer análise que se faça acerca de cursos de graduação deve considerar as diretrizes que norteiam, em âmbito nacional, a criação e renovação de cursos em nível superior. 
Todavia, neste texto, devemos também considerar que o Projeto pedagógico do curso de graduação em Administração Pública - PPCGAP - da Universidade X foi devidamente aprovado em maio de 2010, com a primeira turma no segundo semestre daquele ano, ou seja, o PPCGAP é anterior às DCN da área. Isso contextualiza que o curso, em uma leitura prévia, não apresenta as bases exigidas pelo CNE, em termos de homogeneização de formação comum em Administração Pública.

Os projetos pedagógicos e organização curricular necessitam arranjar conteúdos que "revelem, em uma perspectiva histórica e contextualizada, compromisso com os valores públicos e o desenvolvimento nacional, assim como com a redução das desigualdades e o reconhecimento dos desafios derivados da diversidade regional e cultural" (CNE, art. $5^{\circ}$ ). O inciso IV, do parágrafo $1^{\circ}$ do mesmo art. $5^{\circ}$ indica que, na formação básica do administrador público deverão ser abordados "conteúdos relacionados, nas diferentes áreas disciplinares, à realidade histórica e contemporânea da sociedade e do Estado brasileiros".

Isso já nos leva a uma possível perspectiva integrada com questões sociais e dissociada do pensamento dominante de escolhas principais de temas gerais. O PPCGAP situa duas bases: a formação humanista e o ethos democrático. A base formativa, segundo o documento é orientada pelos "princípios constitucionais da legalidade, impessoalidade, moralidade, publicidade e eficiência e da transparência da Administração Pública assim como a aplicação de ferramentas de gestão pública" (Universidade X, 2010, p. 26).

Tendo em vista a leitura das DCN associada com o contido do PPCGAP, entendemos a formação humanista como a busca, por meio de disciplinas do currículo e pelas diversas atividades extracurriculares oferecidas, de sensibilizar os alunos para questões sociais, políticas, culturais e éticas relativas ao país e às profissões de uma forma geral. Já ethos é uma palavra de origem grega, que significa "caráter moral" e, associada ao princípio democrático, tenderia a se relacionar com uma formação proposta à incitar comportamentos e valores democráticos na perspectiva da Administração Pública (Universidade X, 2010; CNE, 2014).

O currículo do curso de Administração Pública da Universidade $X$ consta de dois eixos de conteúdo: um de formação básica e outro de especialização. A formação básica é constituída por disciplinas que visam propiciar ao aluno uma visão geral dos aspectos legais, sociais, econômicos e políticos que caracterizam a Administração Pública brasileira, enquanto que a especialização é destinada à formação do administrador público, direcionada por dois eixos de formação - Elaboração e Gestão de Políticas Públicas; Gestão de Orçamento e Finanças Públicas -, no que diz respeito aos princípios constitucionais da legalidade, impessoalidade, moralidade, publicidade e eficiência e da transparência da administração pública assim como a aplicação de ferramentas de gestão pública.

O PPCGAP se diz afirmar como um projeto pedagógico promotor de uma educação com viés "crítico", pautado pelo "ethos democrático e republicano", voltado para resolução dos "problemas sociais" e que permite aos graduandos terem "capacidades preventivas" e de "análise de soluções". Contudo, em momento algum o PPCGAP se refere a questões 
como desigualdades socioeconômicas, políticas e institucionais. Seria expectativa demais se pensar que o referido projeto pudesse ter menção às desigualdades referentes à gênero, raça e LGBTT, seja por motivos conservadores, seja por motivos de não se observar tais possibilidades como desigualdades de fato.

As diretrizes curriculares apontam para uma formação crítica do administrador público que compreenda não somente a base técnica que sustenta a gestão pública, mas a base conceitual, ideológica e de cidadania que, por ventura, impacte nas políticas públicas, arranjos institucionais e formas diretivas de atuação e intervenção estatal. A perspectiva da cidadania prevista na Constituição Federal de 1988 situa a mesma no sentido de o Estado institucionalizar as condições básicas de vida digna e respeito à pessoa humana (art. $5^{\circ}$ ). Isso comporta as ideias de empatia, tolerância, respeito às diferenças, compreensão da heterogeneidade e não discriminação por cor, gênero, raça, inclinação religiosa, política, associativa e demais aspectos do âmbito da sociabilidade, posicionamento e identidade.

Por conta disso é basilar que projetos político-pedagógicos de cursos de graduação em Administração Pública procurem reorientar seus escopos, conceitos, disciplinas, projetos, eventos, estratégias de ensino e sobremaneira, influenciar docentes a lecionar, produzir conteúdo e criar atividades extensionistas que movimentem o corpo docente, como um todo, em conjunto com alunos e técnicos universitários na perspectiva inclusiva da cidadania. Essa perspectiva não pode ser paliativa, nem provisória, deve fazer parte conceitual, em práticas e discursos verbais e não-verbais do curso de graduação.

Se as DCN direcionam para uma formação humanística que compreenda a variabilidade social, cultural, política e ideológica, isso significa que o Estado e a Administração Pública, via gestores, não pode estar indiferente às questões sociais que afetam a dignidade humana e que vêm sendo problematizadas no âmbito da atuação e intervenção estatal no sentido de se criar condições materiais objetivas para o bem comum.

Questões como a igualdade de gênero, racismo e políticas afirmativas e a homofobia vêm sendo discutidas por órgãos do governo nos três níveis e pela sociedade civil para que se tenha um amplo e profundo debate na produção de políticas públicas voltadas a esses segmentos. $E$ aqui cabe o questionamento se a formação do administrador público é capaz de proporcionar base o suficiente para que o mesmo possa problematizar e compreender, além de ter capacidade criativa para elaborar propostas para o desenvolvimento de ações específicas que sejam efetivas e não paliativas. $O$ compromisso com o bem comum se refere a todos e não comum a um determinado grupo dominante política, cultural, social, institucional ou financeiramente. É fundamental na formação a inclusão de temas que costumam ser negligenciados pela Academia e pela gestão pública em si por serem custosos e exigirem posicionamento crítico de uma realidade negativa que a própria Academia e gestão pública ajudam a construir.

Tendo em vista que elencamos três dimensões da desigualdade social - gênero, raça e diversidade sexual -, situamos alguns elementos específicos destas três dimensões e suas correlações com projetos políticos pedagógicos. Notadamente, as pessoas vinculadas na análise destas três dimensões costumam ser associadas aos grupos minoritários. 
Zago (2006) rompe o entendimento do conceito de minorias, geralmente apreendidas de forma distante do sentido original. As minorias seriam em sentido político, uma vez que, considerados outros elementos, as mesmas não seriam consideradas enquanto tal. Se entendermos, por exemplo, que mulheres e negros fossem minorias no âmbito da apreensão de políticas públicas, estaríamos desconsiderando de que se tratam de mais da metade da população brasileira, em termos de gênero e raça, respectivamente. No âmbito do acesso e permanência no ensino superior estaríamos frente não a uma minoria, mas sim de uma maioria significativa excluída do sistema de ensino superior brasileiro.

O racismo é um elemento estrutural da sociedade brasileira, sendo construído e reconstruído a cada momento histórico a partir da conjuntura social, política, econômica e embasada por elementos científicos, fazendo parte do elemento estrutural de comportamento social (Schwarcz, 1993). É elemento estrutural por estar relacionado, primeiramente, à ordem social, ou seja, base institucional e de relações sociais, mas, ainda, por estruturar o sistema de acesso às oportunidades, renda e trabalho, segurança e saúde.

Historicamente, negros detém a desvantagem institucionalizada, seja normativamente, seja por convenções sociais, de aceso aos recursos públicos, ao Estado e à cidadania. Não obstante, o período escravista brasileiro, que perdurou oficialmente até 1888, com a Abolição da Escravatura, os negros ainda convivem com os resquícios da escravidão ${ }^{1}$, materializados no preconceito e discriminação, que perduram em elementos culturais, educacionais, familiares e institucionais mais de um século posterior ao ato.

Neste contexto das políticas orientadas pela reformulação de resultados, estariam as políticas afirmativas, cujo objetivo é assegurar diversidade no domínio de atividades públicas e privadas (Passos, 2015), assim como acumular a presença dos grupos nas diferentes esferas da vida; é também acabar com déficit de cidadania. Em certo sentido, as políticas afirmativas teriam como objetivo, não apenas tornas mais justas as condições materiais de disputa, mas reformular os resultados posteriores as partir da implantação das mesmas.

Para Passos (2015, p. 163), "os novos sujeitos que entram em cena na universidade trazem consigo as marcas de suas trajetórias de desigualdades e questionam a cultura acadêmica instituída". É interessante a autora utilizar o termo "trajetórias de desigualdades" como algo analítico em termos de formulações, tanto teóricas quanto empíricas, no âmbito das políticas públicas, especificamente para o sentido afirmativo. Ao implementar estas políticas, estariam as universidades começando a mudar sua cor, classe e gênero?

"As cotas estão forçando a que os acadêmicos finalmente se vejam como brancos e não como cientistas" (Passos, 2015, 165). Essa frase situada por Passos (2015) é elementar de como o silenciamento e a meritocracia são instituidoras de projetos culpabilizadores. As cotas, ao ampliarem a base social de acesso ao ensino superior, são

\footnotetext{
${ }^{1}$ Angela Davis (2016) e Antonio Alfredo Guimarães (2009) fazem análise disso, respectivamente, nos EUA e no Brasil. 
capazes de produzir, nas pessoas brancas, o reconhecimento ou não de seus privilégios e de como instituem um lugar de fala, onde predominam em boa parte, por sua condição de cor e raça. A sociedade" não é uma categoria unívoca, e privilégios de cor e raça devem ser expostos, questionados e excluídos.

Guimarães (2009), ao citar a questão de que, no Brasil, se tem o preconceito de se ter o preconceito, ou seja, onde o racismo é negado publicamente, temos de considerar que, ainda que se tenha essa negação, o racismo se perpetua nas práticas cotidianas, nos discursos verbais e não-verbais, principalmente estes últimos, que, num primeiro momento, expressam o reflexo de um sistema de dominação e, em segundo, classifica, inferioriza e justifica as assimetrias de uma relação de poder.

Isso nos leva a pensar que em um curso de graduação em Administração Pública, a dimensão da desigualdade raça deveria fazer parte dos projetos políticos. Em pesquisa acerca do PPCGAP da universidade X, Baptista (2017) verificou que apenas uma única disciplina do curso apresenta em sua ementa um autor negro em suas referências bibliográficas, no caso, Milton Santos.

No contexto do reconhecimento com a finalidade de se buscar ações concretas pautados pela base democrática, Hruschka e Maio (2015) a partir do âmbito escolar, mas que pode ser empregada no âmbito universitário, entendem que "as escolas precisam desenvolver mecanismos democráticos diante da diversidade sexual e para falar em diversidade sexual é necessário buscar o entendimento de sexo e gênero" (p. 81). Para tanto, é necessário também o reconhecimento dos mesmos como detentores do acesso ao espaço e recursos, tais como outros já plenamente reconhecidos. Necessita-se valorizar segmentos negligenciados e eliminar preconceitos e dogmatismos.

Wollstonecraft (2016), no âmbito da questão de gênero, aborda essa base ao procurar analisar a correlação entre senso comum, preconceitos, verdades e a razão. Entende que preconceitos obscurecem a razão e servem como guias no comportamento humano, relações sociais, mas, sobretudo, servem como verdades para a sociedade como um tudo. Os preconceitos enraizados nos indivíduos e na sociedade "obscureceram a razão e qualidades tão espúrias usurparam o nome de virtudes, faz-se necessário percorrer o curso da razão" (p. 31). De certa forma, isso tende a ser perigoso, uma vez que esses preconceitos, sem qualquer base de pensamento e reflexão orientam a vida em sociedade. E ainda mais, como preconceitos geralmente discriminam determinados grupos ou indivíduos, isso significa que, esses preconceitos orientarão a vida em sociedade, servindo como verdades incontestáveis. Aqui, é importante entender, então, o papel da Universidade em deslegitimar os preconceitos como a base racional.

As autoras sustentam, neste contexto, o papel dos projetos político-pedagógicos que se tornam "um documento vivo e que serve de parâmetro para discutir referências, experiências e ações" (Hruschka; Maio, 2015, p. 82). Tal prerrogativa se entende a partir da perspectiva em que a universidade venha a construir mecanismos de aprendizagem que contemplem a todos, fornecendo, desta forma, as práticas de ensino. Essa possibilidade permite não apenas se discutir as diferenças e os preconceitos, mas também incita a debater a reprodução dos ciclos de violência e discriminação, em que o foco recai nas atitudes e comportamentos. 
O projeto político-pedagógico, apesar de potente, não é capaz de sozinho, desestruturar o status quo e reestruturá-lo em novas bases democráticas, com equidade, justiça social e ambiente plural e aberto às diferenças. A comunidade à qual o projeto está vinculado precisa aprender e apreender novas práticas que rompam com a negligência e o silenciamento e construam um ambiente inclusivo e democrático.

Minella (2013) destaca a importância de se ter em mente as questões de gênero, especificamente, quanto à discriminação, pelo viés da interseccionalidade, elaborado por Kimberlé Crenshaw e entendido como "associação de sistemas múltiplos de subordinação" (p. 98). O que também já é discutido por Davis (2016) e Hooks (2013), ao enfatizarem o uso dessa abordagem, por entenderem as perspectivas do "feminismo branco" como essencialistas, além de afastarem a perspectiva das mulheres negras. Butler (2016) também já tinha observado, não a questão da interseccionalidade, mas as estratégias totalizantes e essencialistas de existência e concepções de gênero e sexo.

Minella (2013) ressalta o sentido de não se entender a complexidade dos sistemas de subordinação como fatos isolados, sistemas fechados, em que cada discriminação funcionaria com suas lógicas especificas e à sua maneira, pelo contrário, os sistemas discriminatórios são abertos e complexos, potencializados entre si, não-hierarquizantes e não-totalizantes. Esse reconhecimento, pela ótica do não silenciamento em Walker (2011) abre margens para análises profundas acerca dos mecanismos estruturantes, atores, processos culturais, sociais, políticos e institucionais que engendram as bases das discriminações. As discriminações de gênero, raça/etnia, sexualidade, classe e renda conversam entre si, ajustam os mecanismos entre si e atuam de forma interconectadas.

Esta estratégia rasa, de simplificar os sistemas de desigualdade tem a ver com o entendimento do campo científico ser um lugar de luta, mais ou menos desigual, entre agentes dotados de capital específico. A questão de gênero, por exemplo, no âmbito dos projetos políticos pedagógicos na universidade deixa isso claro. A fragmentação e reducionismo estão presentes. As desigualdades se restringem no campo do objeto, às esferas do âmbito econômico e educacional. Todos, na conjuntura das desigualdades, são achatados e, consequentemente, homogeneizados - trata-se de processo de ocultação dos mecanismos estruturantes das desigualdades.

Minella (2013) realiza um profícuo estudo em que analisa as temáticas gênero e ciências no Brasil, entendendo que ainda há um longo caminho que afaste as análises das perspectivas rasas, dos preconceitos de gênero e classe como base racional - como alerta Wollstonecraft (2016) - na produção científica, da desmistificação de correlações entre sexo e campo científico, dentre outros.

A ideia base defendida pela autora corrobora a presente pesquisa pelo fato de incitar debates em que se analisem a produção e reconhecimento de pesquisas realizadas por mulheres em áreas de conhecimento que apresentam alto grau discriminatório e de pouca aceitação. Assim como a desmistificação dos campos das Ciências Humanas e Sociais como aquelas naturais de produção científica de mulheres. Tem-se então uma espécie de visão androcêntrica sobre a cultura acadêmica - o lugar das mulheres de um lado mais raso e pouco cientifico, e o lado dos homens, em outro campo, mais atrelado ao científico de fato. Contudo, as perspectivas são totalizantes, quando não essencialistas, acerca das experiências das mulheres. Como se todas padecessem da mesma curva de experiência. 
A questão da raça/etnia, para a autora, inda compõe uma grande lacuna: "chama a atenção que não se problematize, por exemplo, o fato de que as cientistas pioneiras sejam, em geral, brancas e oriundas de famílias de imigrantes europeus (Minella, 2013, p. 126). Não se pode afirmar que isso se trata de escolha teórica ou negligência de fato, assim como resultado de falta de dados. O que convém apontar é que não se abordou e ainda não se aborda, o que se configura em um espaço em que a ciência apresenta, claramente, um viés representativo e configurante de gênero, raça e classe.

Minella (2013) insiste que não convém apenas falar na falta de dados, para que se produzam ou se tivessem sido produzidos tais pesquisas. Essa falta de pesquisas também resulta da "falta de pressão política das próprias pesquisadoras do campo [de gênero e ciências]" (p. 128). Isso corrobora a ideia de que a abordagem de certos temas, o uso de metodologias e vieses analíticos configuram uma escolha política que envolve, sobretudo, a definição de um posicionamento. Assim, isso nos motivou a investigar as noções que alunos do curso de graduação em Administração Pública da universidade $X$ acerca das três dimensões de desigualdade: gênero, raça e diversidade sexual.

\section{As dimensões de gênero, racismo e diversidade sexual no curso de graduação em Administração Pública da universidade $X$}

A pesquisa de campo teve como objetivo capturar o contexto em que os alunos observam a questão de gênero, raça e homofobia no âmbito do curso de graduação em Administração Pública da universidade $X$. Convém salientar que o questionário não teve como objetivo analisar profundamente cada vertente de nosso objeto de pesquisa: o objetivo em si foi o de levantar insights significativos que nos permitissem, futuramente, voltar ao campo para, então, realizar mais profundamente uma análise que permitisse conclusões e apontamentos mais robustos. Todavia, os resultados obtidos nos permitiram alcançar este levantamento prévio.

O questionário foi composto de perguntas no sistema dicotômico e plural, com perguntas abertas e fechadas, totalizando 23 questões. O questionário foi disponibilizado por meio de link eletrônico e enviado, por e-mail, a todos os estudantes com matrícula ativa no curso de graduação em Administração Pública da universidade $X$ durante o mês de abril de 2017 por quinze dias consecutivos. Existem sete turmas com matrícula ativa no momento: 2010, T2011, T2012, T2013, T2014, T2015 e T2016, uma vez que o curso de graduação em Administração Pública da Universidade $X$ foi criado em 2010 e conta com uma única entrada anual de alunos novos.

Tendo em vista que poucos alunos das turmas T2010 e T2011 não impactariam na amostragem, decidimos não contabilizar estas turmas e manter, para análise, apenas cinco turmas: T2012, T2013, T2014, T2015 e T2016, totalizando 158 alunos com 16, 32, 37, 29 e 44 alunos matriculados respectivamente, em cada turma. Deste universo de 158 alunos obtivemos 53 respondentes, 33,5\% de sucesso, com 6, 15, 9, 10 e 13 respondentes para as turmas T2012, T2013, T2014, T2015 e T2016 respectivamente, conforme pode ser observado na tabela a seguir. 
Figura 1 -

Amostragem e universo.

\begin{tabular}{l|llllll}
\multicolumn{1}{l}{} & 2012 & 2013 & 2014 & 2015 & 2016 & Total \\
\hline Universo & 16 & 32 & 37 & 29 & 44 & 158 \\
Respondentes & 6 & 15 & 9 & 10 & 13 & 53 \\
$\%$ & 37,5 & 46,9 & 24,3 & 34,5 & 29,5 & 33,5
\end{tabular}

Fonte: Elaborado pelo autor.

Feita esta consideração, podemos indicar alguns resultados gerais referentes ao contexto docente e estudante para, em seguida, adentrar no aspecto das dimensões de gênero, raça e homofobia. Existe uma tendência à concentração de mulheres nas turmas, exceto a T2014, que responderam ter mais homens que mulheres. Nas turmas T2012 e T2016 há predominância de mulheres, o que reflete na nova configuração do ensino superior, em que o número de matriculas de mulheres supera a de homens. Contudo, essa configuração se alterna no âmbito dos docentes, em que três turmas dentre duas indicam ter tido mais docentes do sexo masculino do que feminino: em uma turma há leve equilíbrio e em outra turma há predominância de docentes mulheres. Ademais, convém situar que existem mais mulheres brancas do que mulheres negras em indicados todas as turmas. Por fim, ressaltamos que as mulheres são parte esmagadora das turmas e todas as turmas indicaram participação ativa das mesmas e poucos casos de restrição, por parte masculina, com exceção da turma T2016, em que 5 estudantes indicaram a tentativa de restrição às mulheres.

Quando perguntados se confiam mais em um docente do sexo masculino ou do sexo feminino ou em ambos, existe um equilíbrio para ambos, 27 respondentes, contudo, percebemos tendência para que não se faça distinção, ainda que alguns alunos indiquem confiança em um ou outro sexo, 8 em homens e 18 em mulheres, como pode ser visto na figura a seguir. 
Figura 1 -

Confiança mediante sexo.

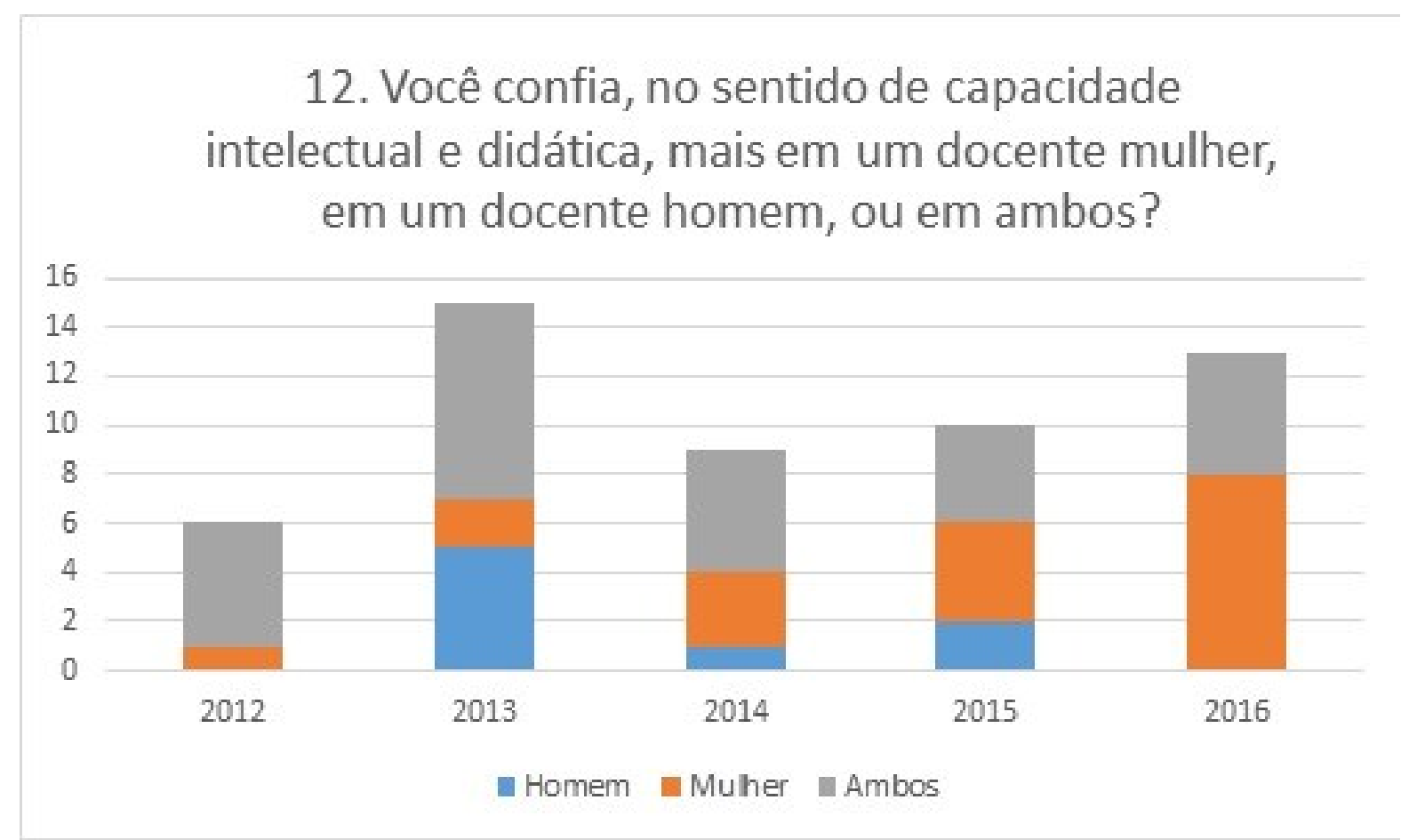

Fonte: elaborado pelo autor.

Existe a percepção de que a vestimenta de mulheres pode atrapalhar o andamento da aula, ainda que tenhamos respondentes afirmando maciçamente o contrário. Apenas a turma T2013 manteve o mesmo número de respondentes, três alunos, desta questão na pergunta seguinte, que observava a existência ou não de graduações especificas para mulheres e para homens. É possível ter coerência entre estes três alunos respondentes. Nas outras turmas - T2012, 2014, T2015 e T2016 - teve ligeira diminuição. Estas duas questões podem ser observadas nos gráficos a seguir. 
Figura 2 -

Percepção de gênero em cursos de graduação.

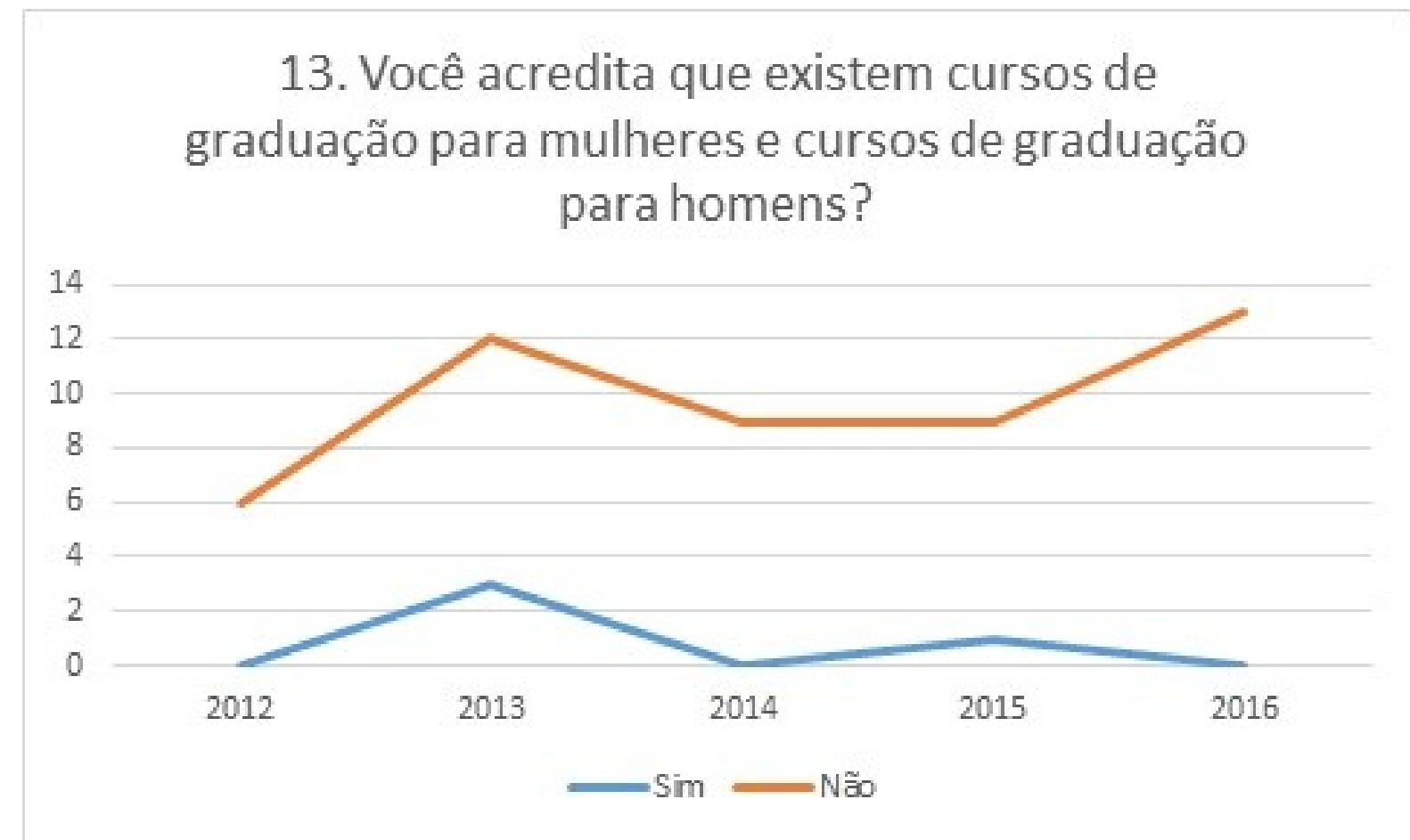

Fonte: elaborado pelo autor.

Figura 3 -

Percepção sexual de gênero.

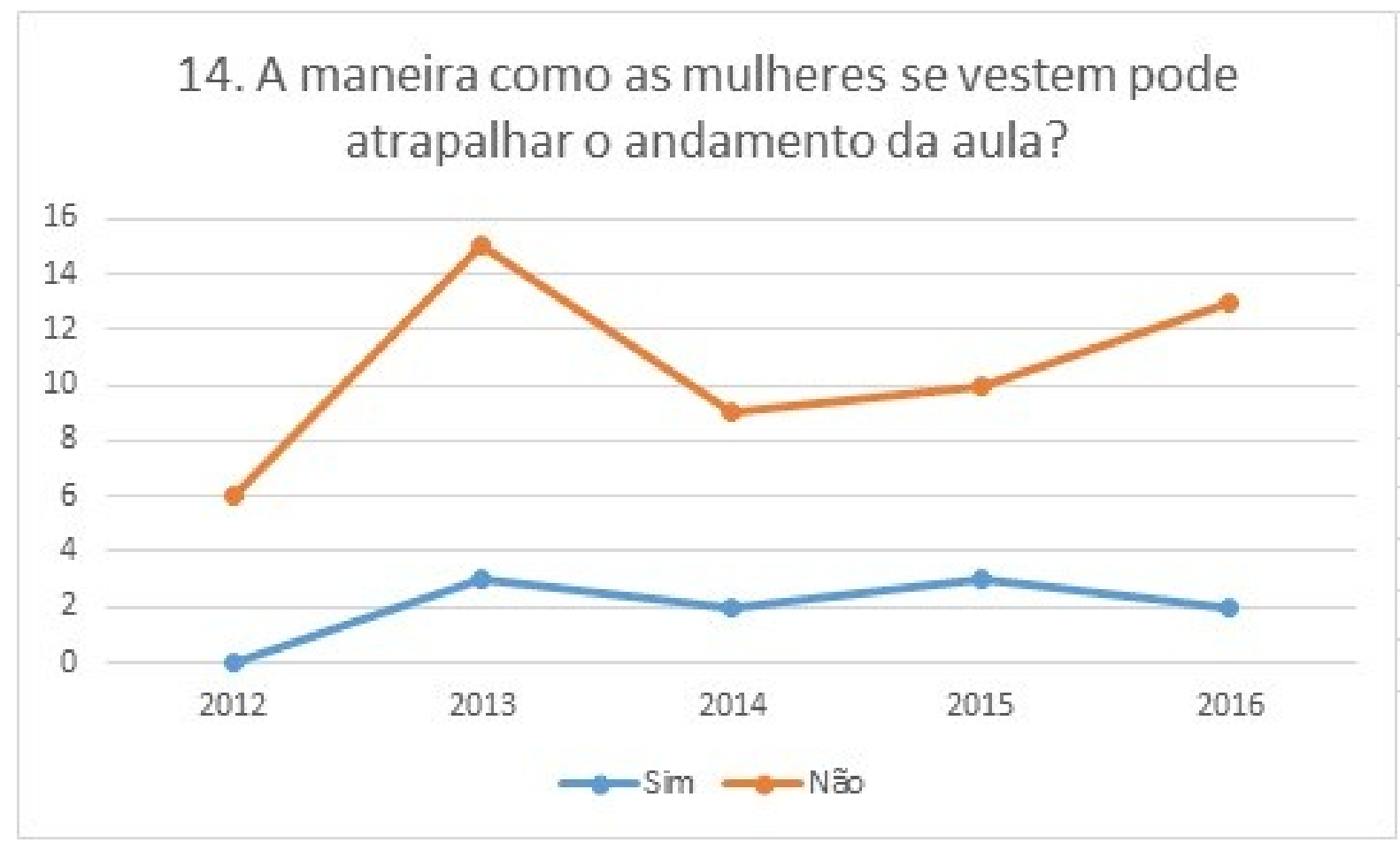

Fonte: elaborado pelo autor. 
Sobre a dimensão de gênero, ressaltamos três aspectos: em 4 das 5 turmas foram indicado títulos de leituras de autoria feminina, notadamente, as bibliografias elaboradas por professoras dos cursos de graduação e pós-graduação da Universidade X. Há presença de bibliografias de autoras nacionais e estrangeiras. A turma T2016, com 10 dentre 13 respondentes, afirma não ter lido autores do sexo feminino.

Figura 4 -

Composição de bibliografia.

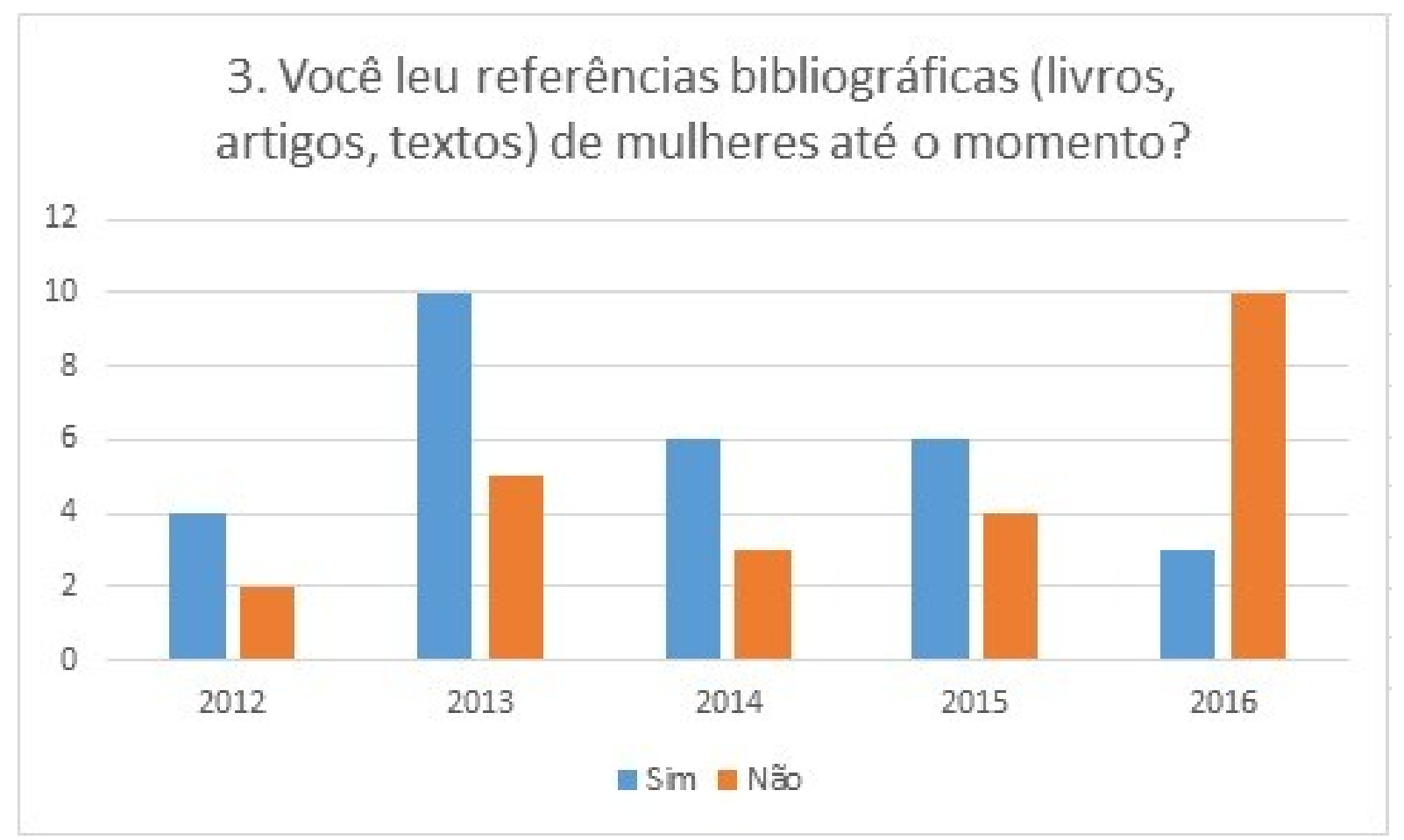

Fonte: elaborado pelo autor.

Ainda que várias autoras tenham sido lidas, isso não garante que a perspectiva do gênero seja debatida em algum momento, já que termos relativo equilíbrio dentre respondentes no que se refere à questão de gênero ter sido debatida em algum momento. A turma T2016, com 10 dentre 13 respondentes afirma que não foi debatida. Também perguntamos se o estudante se sente incomodado quando são discutidas temáticas referentes ao empoderamento e relevância das mulheres e obtivemos três respostas, dentre 53 , de estudantes que se sentem incomodados. 
Figura 5 -

Percepção da abordagem de gênero em sala de aula.

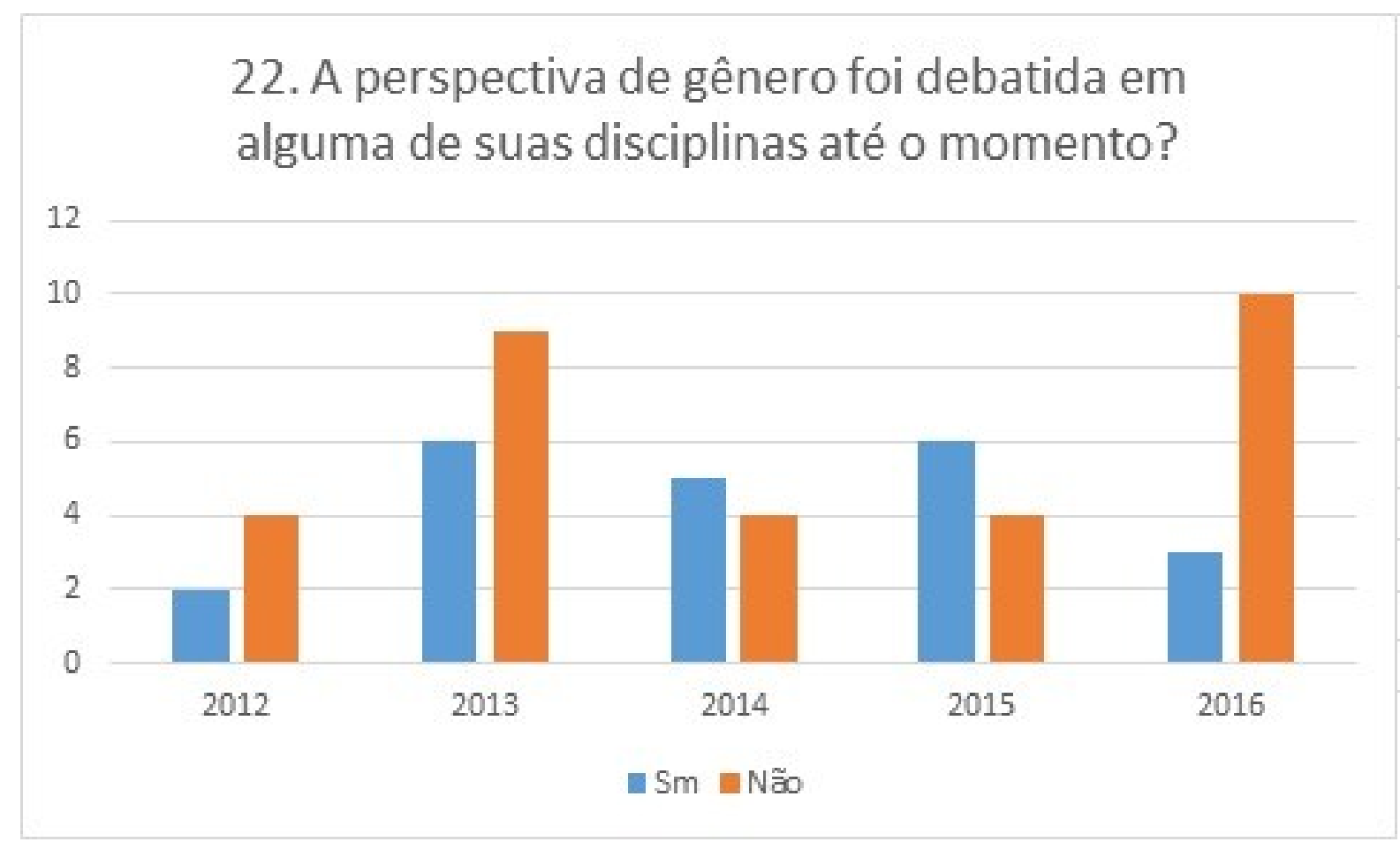

Fonte: elaborado pelo autor.

No que se refere à dimensão de raça, também temos três apontamentos. Ao contrário da dimensão de gênero, parece que o racismo tem a tendência de ser mais debatido em sala de aula, com a maioria das turmas, exceto T2016, afirmando ter debatido.

Em segundo, a maioria dos respondentes de todas as turmas afirmam não ter lido referências bibliográficas de autores negros. Isso significa que a perspectiva racial vem sendo discutida pela vertente de autores brancos. Neste sentido, alguns alunos situaram que não veem necessidade em saber se os autores são negros, contudo, são incapazes de citar um autor. Outro aluno diz que "não sei responder, pois esta pergunta não faz sentido, quem lê um livro baseado na cor do autor!" 
Figura 6 -

Composição bibliográfica por raça.

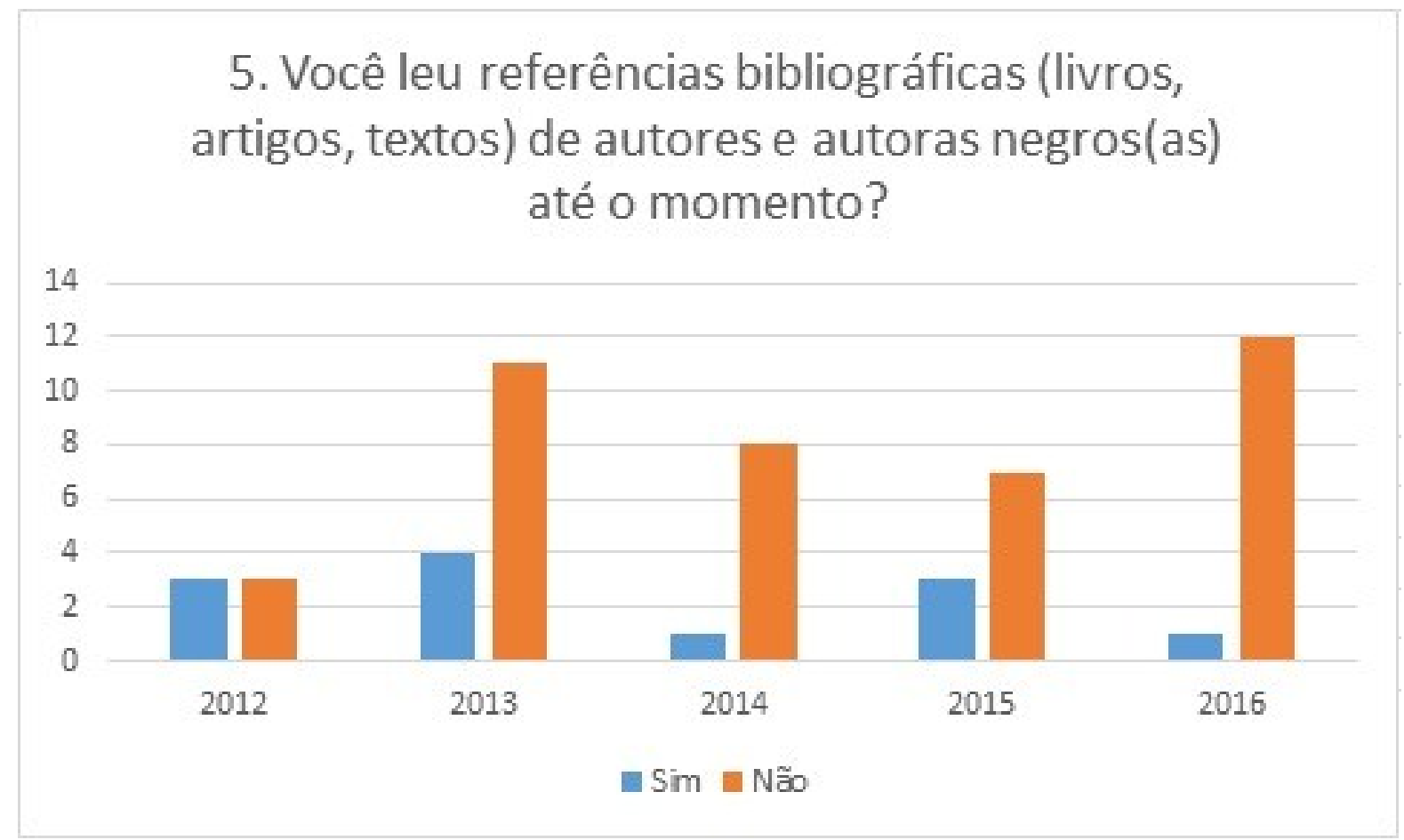

Fonte: elaborado pelo autor.

Figura 7 -

Percepção de abordagem de diversidade sexual em sala de aula.

20. A diversidade sexual foi debatida em alguma de suas disciplinas até o momento?

10

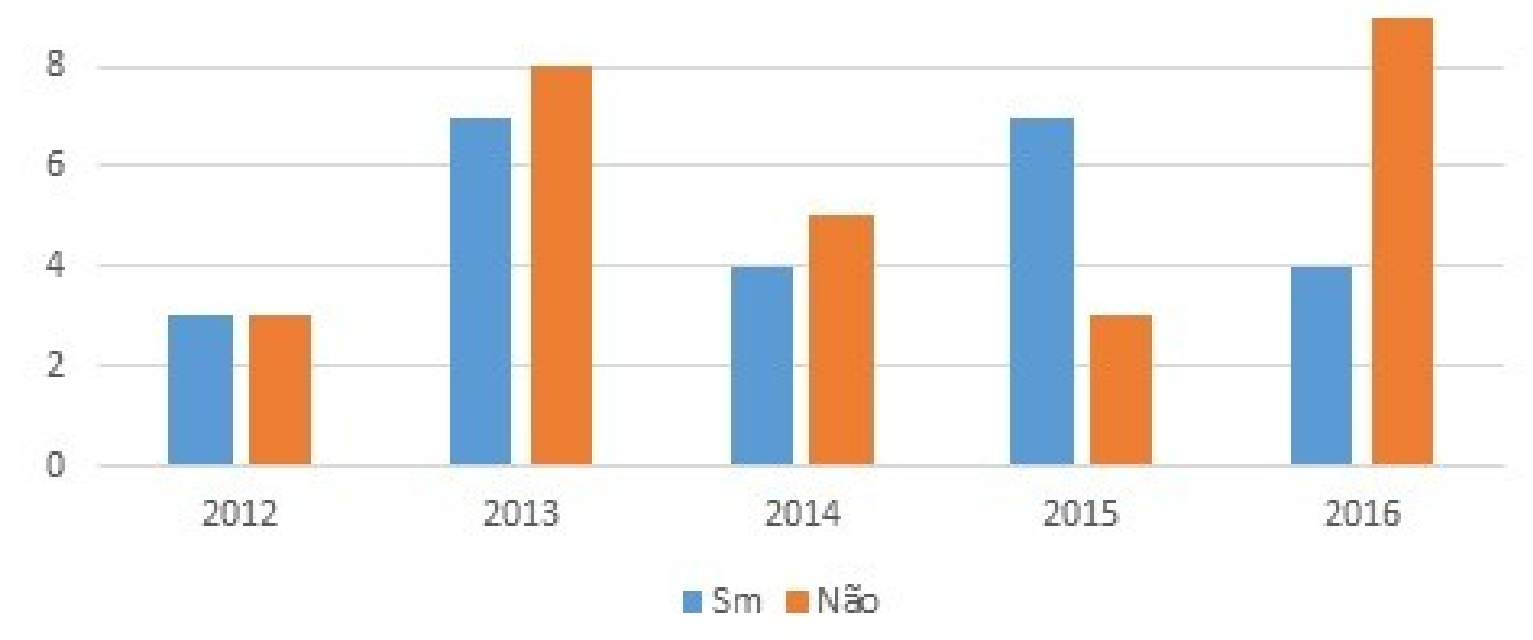

Fonte: elaborado pelo autor. 
Ainda neste item um aluno citou ter lido autores negros em disciplina específica optativa, fora da grade e à escolha do aluno, sobre relações étnico-raciais. Mas precisaríamos ter disciplinas específicas para aumentar a bibliografia de autores negros? Duas referências foram citadas: uma professora da Universidade $X$, via material didático que produz para suas aulas, e Milton Santos que, aliás, é a única referência negra dentre as ementas analisadas no curso de graduação em Administração Pública da Universidade X (Baptista, 2017) ${ }^{2}$.

Por último, na dimensão de diversidade sexual, situamos dois apontamentos: a) a diversidade sexual, em termos de propensão ao debate em sala de aula, é a que mais apresenta, em 3 das 5 turmas, maior equilíbrio dentre os que responderam que sim e que não; b) já as turmas T2015 e T2016 apresentam dados diversos enquanto que a maioria da turma T2015 afirma ter debatido a diversidade sexual em alguma disciplina e a maioria da turma T2016 afirma que isso não ocorreu.

Figura 8 -

Incômodo sobre temáticas de diversidade sexual.

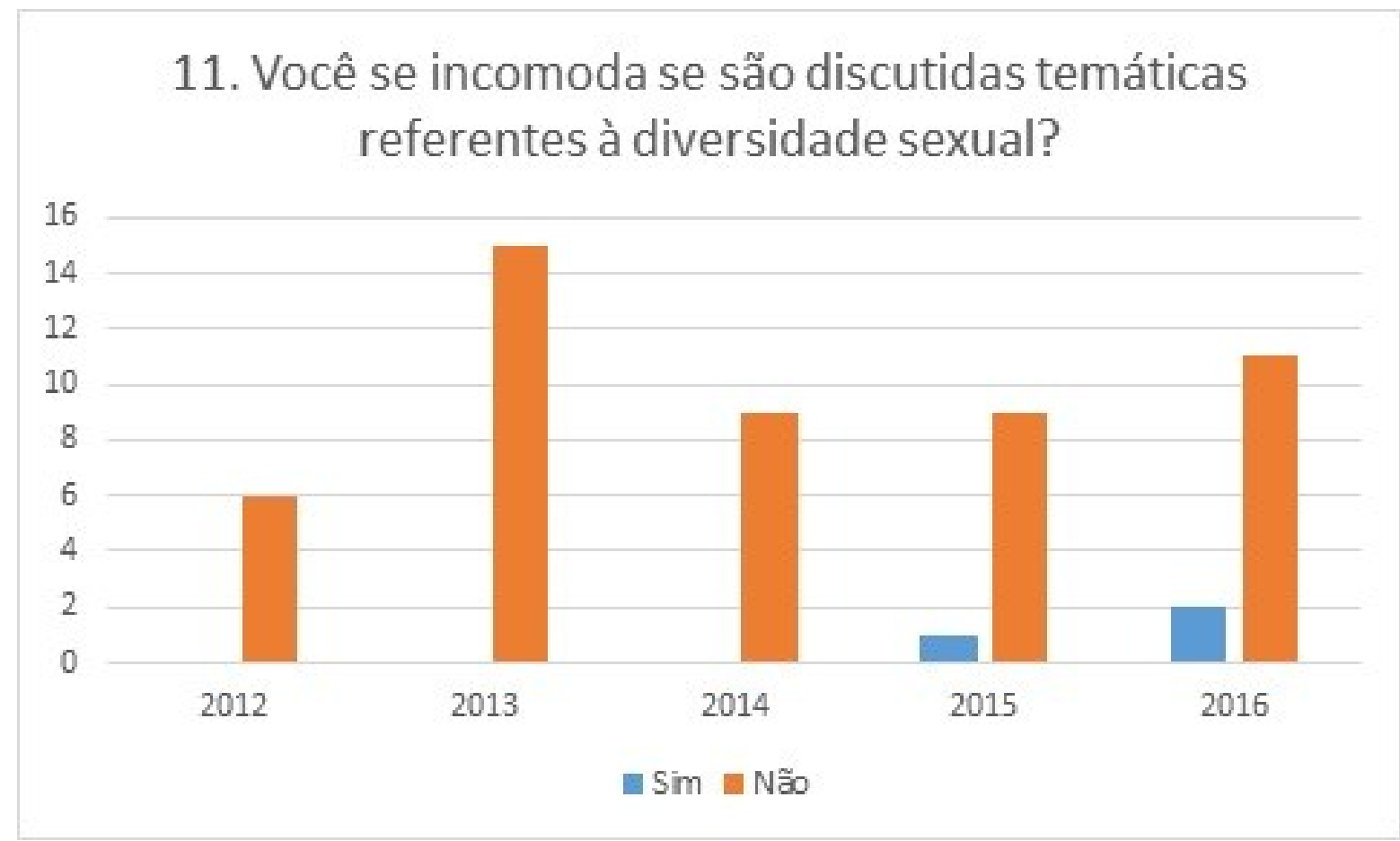

Fonte: elaborado pelo autor.

Por fim, há de se ressaltar que quase a totalidade dos alunos das cinco turmas, excetuando um aluno da turma T2015 e dois alunos da turma T2016, afirma não se incomodar se as temáticas de diversidade sexual são discutidas em sala de aula.

\section{Discussão}

Situamos, de modo geral, que este primeiro contato com os estudantes do curso de graduação em administração pública tem caráter "introdutório", ou seja, mapear

\footnotetext{
${ }^{2}$ A análise das ementas do curso de graduação em Administração Pública da UFFRJ foi objeto de outra pesquisa, cujos resultados podem ser observados em Baptista (2017).

\begin{tabular}{|l|l|l|l|l|l|} 
Regae: Rev. Gest. Aval. Educ. & Santa Maria & v. 7 & n. 14 & Jan./abr. 2018 & p. 111-133
\end{tabular}
}


determinados elementos que permitam hipóteses e construir um cenário preliminar sobre a questão da discriminação no curso - sobre se este aborda ou renega determinadas questões. Não necessariamente a amostragem não comporia a totalidade dos alunos, uma vez que os resultados obtidos não apresentariam contradições nas tendências, todavia, para análise mais profunda, totalidade deve ser alcançada.

Conforme as turmas evoluem no processo formativo, tendo contato com mais disciplinas e docentes, a tendência é que vão tendo aproximação com diversos conteúdos voltados às três dimensões. Isso é percebido no fato de que quanto mais antigas forem as turmas, maior a tendência de que citem autores negros e tenham contato com autoras. Ainda: quanto mais novas são as turmas, maior a tendência de, além de desconhecerem bibliografia, também a possibilidade de apresentarem resistências e desconforto na abordagem das três dimensões.

Não há uma distribuição homogênea no que se refere à distribuição das disciplinas, no sentido de abordagem, direta ou indireta, das três dimensões. Enquanto que no Ciclo Básico se tem 14 disciplinas ofertadas, com 5 delas correlacionadas de alguma forma, temos 8 disciplinas dentre 10 que possuem alguma correlação com as três dimensões no Ciclo Profissional. E isso corrobora a noção de que o fluxo de disciplinas vai, de alguma forma, ampliando, via ementas e esforços criativos dos docentes, notadamente pela criação particular de material didático de apoio, a possibilidade de abordagem das três dimensões.

Aquilo o que não é lembrado e aquilo que não é visto em sala de aula, não pode ser discutido: é fundamental um esforço no sentido de se rever ementas e processos pedagógicos dentro, não apenas no âmbito do curso de graduação em Administração Pública, assim como, sobretudo, na matriz da Universidade $\mathrm{X}$ como um todo.

Alguns dados, ainda que relativamente pequenos se levados em consideração a amostragem, são significantes pelo fato de que, por representarem amostragem, podem indicar posicionamentos de estudantes para a Universidade $X$ de forma ampliada. Não há como desconsiderar que tem estudantes que se incomodam com a abordagem de temáticas referentes à gênero, racismo e diversidade sexual, além de não verem a universidade como o espaço ideal para discutir estas temáticas.

Ainda: quatro estudantes responderam que existem cursos de graduação adequados para homens e outros para mulheres e três destes estudantes as da turma T2013, relativamente antiga e que já teve contato com boa parte do conteúdo do curso. Também não há como desconsiderar que uma regularidade de dois a três estudantes por turma afirma que a maneira como as mulheres se vestem pode atrapalhar o andamento das aulas, a exceção foi a turma T2012 com zero de respondentes.

Alguns indicativos que estes dados também podem trazer é que, pelo fato de que as três dimensões serem pouco discutidas, ainda que, por exemplo, tendo bibliografias citadas por estudantes, se terá resistência e pouca abertura às mesmas, gerando incômodos quando, de fato, são abordadas. E quanto menos se abordassem as três dimensões, ainda se terá a naturalização de papeis de mulher e de homem, cada um com sua graduação específica às suas características, assim como a naturalização da mulher como provocadora de assédios por conta de sua vestimenta. 
Por fim, ao se negligenciar, propositadamente, a abordagem das três dimensões, ou de outras que tratem de grupos sociais marginalizados, mais se põe em xeque a universidade como local de debate e reflexão sobre ideias e problemas sociais.

\section{Considerações finais}

Procuramos problematizar como as dimensões de desigualdade social estão percebidas em estudantes em curso de graduação em uma universidade federal. As dimensões trabalhadas envolvem as desigualdades sociais no que referem à gênero, raça e diversidade sexual. O objetivo então foi discutir a percepção de estudantes de um curso de graduação em Administração Pública em relação às dimensões de desigualdades sociais de gênero, raça e diversidade sexual e visualizar a necessidade de que o curso, em seu projeto político pedagógico, reforce o trabalho interdisciplinar destas dimensões em seu currículo.

O fundamental dessa discussão é construir uma nova agenda que force atitudes políticas, debates públicos e, sobretudo, reconhecimento, sobre as desigualdades raciais e o racismo estrutural, em especial no âmbito educacional, lócus privilegiado onde os estudantes estão diretamente vinculados. Como situado por Alice Walker (2011), o silêncio é um ato político. O não reconhecimento é decorrência também, mas não exclusivamente, do silenciamento dos discriminados, da discriminação e da conjuntura cultural, social e política discriminadora.

O ambiente universitário, tradicionalmente, é um ambiente reservado, fechado às elites política, econômica e cultural, com melhores condições de disputar o sistema meritocrático que as universidades entendem e exigem ser a melhor forma de seleção e permanência de estudantes. Como os recursos seriam escassos para a universalização do ensino superior, deveriam, nesta lógica, existir mecanismos de seleção apenas dos melhores.

É papel da administração pública incitar a promoção da igualdade no Brasil, com o objetivo de estruturar não somente a igualdade de oportunidades, em que os acessos aos recursos públicos sejam mais equitativos e equilibrados, sem privilégio à grupos ou classes dominantes. O objetivo é também criar uma igualdade de resultados, em que sejam observadas bases pós-implantação das políticas, dentro da própria formulação de políticas públicas, ou seja, elementos que não se restrinjam apenas em criar oportunidades, mas que, após criadas, estas produzam efeitos quem potencializem as próprias políticas iniciais.

Voltando à questão de problematizar as diversas desigualdades sociais em projetos políticos pedagógicos, se estamos construindo uma base que seja humanista e crítica, tais sujeitos, a partir da exclusão, a questionam, em termos de reprodução no ambiente universitário, a constituição dessas desigualdades. Mas, para o devido questionamento, é necessário o reconhecimento das mesmas como parte intrínseca na compreensão da formação profissional do estudante. Isso traria ao estudante a capacidade para analisar as desigualdades sociais, a conjuntura política, institucional, social, econômica, cultural etc., incitando crítica capaz de também propor soluções pautadas pela cidadania e não a mera gestão das desigualdades. 
Neste sentido, na elaboração ou revisão de um projeto político-pedagógico, as tensões existentes em disputa, seja ideológica, seja de valores, irão impactar na abordagem ou não de determinados aspectos, o que pode, de certa forma, produzir um silêncio. Passos (2015, p. 168) pondera que "os projetos pedagógicos dos cursos são expressões históricas das relações de poder existentes na sociedade e, portanto, na cultura acadêmica" (p. 168), ou seja, o corpo do projeto pedagógico irá nortear a base conceitual dos vencedores ou dominantes.

Contudo, a existência de uma base mecânica e engessada nos projetos políticopedagógicos conduz a um processo inverso no estudante: a de culpabilização dos sujeitos pelo seu estado de desigualdade, por eles mesmos não serem dignos ou não terem mérito. $O$ projeto político-pedagógico pode servir como norteador para a reprodução, manutenção e ampliação do status quo.

\section{Referências}

ARROYO, Miguel. Políticas educacionais e desigualdades: à procura de novos significados. Educação e Sociedade, Campinas, v. 31, n. 113, 2010, p. 1381-1416.

ATKINSON, Anthony B. Desigualdade: o que pode ser feito. São Paulo: Leya, 2015.

BAPTISTA, Vinicius Ferreira. Diretrizes nacionais e o descompasso na formação humanística do curso de graduação em Administração Pública da UFRRJ. Regae Revista de Gestão e Avaliação Educacional, Santa Maria, v. 6, n. 13, 2017, p. 101-119.

BUTLER, Judith. Problemas de gênero: feminismo e subversão da identidade. Rio de Janeiro: Civilização Brasileira, 2016.

CASTEL, Robert. As metamorfoses da questão social: uma crônica do salário. Petrópolis: Vozes, 2010.

CNE. Resolução CNE/CES n. 1, de 13 de janeiro de 2014. Institui as diretrizes curriculares nacionais do curso de graduação em Administração Pública, bacharelado, e dá outras providências. Disponível em <http://portal.mec.gov.br/index.php?option=com_docman\&view=download\&alias=14957rces001-14\&category_slug=janeiro-2014-pdf\&ltemid=30192>. Acesso em 10 jun. 2016.

DAVIS, Angela. Mulheres, raça e classe. Boitempo: São Paulo, 2016.

DYE, Thomas R. Understanding public policy. 14th. ed. United States: Pearson Education, 2013.

FOUCAULT, Michel. Microfísica do poder. Rio de Janeiro: Graal, 1979.

GUIMARÃES, Antonio Sergio Alfredo. Racismo e antirracismo no Brasil. São Paulo: Editora 34, 2009.

HOOKS, Bell. Ensinando e transgredir: a educação como prática da liberdade. São Paulo: Martins Fontes, 2013.

HOULSTON, James. Cidadania insurgente: disjunções da democracia e da modernidade no Brasil. Companhia das Letras: São Paulo, 2013.

HRUSCHKA, Janete; MAIO, Eliane Rose. Gênero e diversidade sexual: análise dos projetos políticos pedagógicos das escolas públicas estaduais de Londrina/PR - ensino médio. Revista Eletrônica de Educação, v. 9, n. 1, p. 78-89, 2015.

MINELLA, Luzinete, Simões. Temáticas prioritárias no campo de gênero e ciências no Brasil: raça/etnia, uma lacuna? Cadernos Pagu, Campinas, v. 40, 2013, p. 95-140. 
PASSOS, Joana Célia dos. Relações raciais, cultura acadêmica e tensionamentos após ações afirmativas. Educação em Revista, Belo Horizonte, v. 21, n. 2, 2015, p. 155-182.

SASSAKI, Romeu Kazumi. Inclusão: o paradigma do século 21. Revista Inclusão, Seesp/MEC, ano I, n. 1, out. 2005, p. 19-23.

SASSAKI, Romeu Kazumi. Inclusão: acessibilidade no lazer, trabalho e educação. Revista Nacional de Reabilitação (Reação), São Paulo, ano XII, 2009, p. 10-16.

SCHWARCZ, Lilia Moritz. O espetáculo das raças: cientistas, instituições e questão racial no Brasil - 1870-1930. São Paulo: Companhia das Letras, 1993.

UNIVERSIDADE X [UNIVERSIDADE FEDERAL RURAL DO RIO DE JANEIRO]. Projeto pedagógico do curso de Administração Pública. Seropédica: UFRRJ, 2010.

ZAGO, Nadir. Do acesso à permanência no ensino superior: percursos de estudantes universitário de camadas populares. Revista Brasileira de Educação, São Paulo, v. 11, n. 32, 2006, p. 226-237.

WALKER, Alice. Rompendo o silêncio: um poeta diante do horror em Ruanda, no Congo Oriental e na Palestina/Israel. Rio de Janeiro: Bertrand Brasil, 2011.

Vinicius Ferreira Baptista é administrador, professor adjunto no Departamento de Administração Pública na Universidade Federal Rural do Rio de Janeiro, doutor em Políticas Públicas e Formação Humana pela Universidade do Estado do Rio de Janeiro.

Endereço: Universidade Federal Rural do Rio de Janeiro - Instituto de Ciências Sociais Aplicadas - Departamento de Administração Pública - Rodovia BR-465 23897-000 - Seropédica - RJ - Brasil.

E-mail: viniciusferbap2007@hotmail.com.

Wanderson Cesar dos Santos é estudante do curso de Administração Pública na Universidade Federal Rural do Rio de Janeiro, bolsista de iniciação científica (Pibic/CNPq).

Endereço: Universidade Federal Rural do Rio de Janeiro - Instituto de Ciências Sociais Aplicadas - Departamento de Administração Pública - Rodovia BR-465 23897-000 - Seropédica - RJ - Brasil.

E-mail: wanderson.cesar@outlook.com.

Recebido em 22 de outubro de 2017.

Aceito em 3 de dezembro de 2017. 